\title{
Article \\ Mechanical Performance of Concrete Made with the Addition of Recycled Macro Plastic Fibres
}

\author{
Pietro A. Vaccaro ${ }^{1}$, Adela P. Galvín ${ }^{2}$, Jesús Ayuso ${ }^{2}\left(\mathbb{D}\right.$, Auxi Barbudo ${ }^{2, *(\mathbb{D})}$ and Antonio López-Uceda ${ }^{3, *}$ \\ 1 Escuela Internacional de Doctorado, Universidad de Sevilla, Pabellón de México, Paseo de las Delicias S/N, \\ E-41013 Sevilla, Spain; pietroant.vaccaro@gmail.com \\ 2 Área de Ingeniería de la Construcción, Universidad de Córdoba, Campus de Rabanales, Edificio Leonardo Da \\ Vinci, E-14071 Córdoba, Spain; apgalvin@uco.es (A.P.G.); ir2ayuje@uco.es (J.A.) \\ 3 Departamento de Mecánica, Universidad de Córdoba, Campus de Rabanales, Edificio Leonardo Da Vinci, \\ E-14071 Córdoba, Spain \\ * Correspondence: abarbudo@uco.es (A.B.); p62louca@uco.es (A.L.-U.)
}

Citation: Vaccaro, P.A.; Galvín, A.P.; Ayuso, J.; Barbudo, A.; López-

Uceda, A. Mechanical Performance of Concrete Made with the Addition of Recycled Macro Plastic Fibres. Appl. Sci. 2021, 11, 9862. https://doi.org/ 10.3390/app11219862

Academic Editors: Dario De Domenico and Sang-Hyo Kim

Received: 3 August 2021

Accepted: 20 October 2021

Published: 22 October 2021

Publisher's Note: MDPI stays neutral with regard to jurisdictional claims in published maps and institutional affiliations.

Copyright: () 2021 by the authors. Licensee MDPI, Basel, Switzerland. This article is an open access article distributed under the terms and conditions of the Creative Commons Attribution (CC BY) license (https:// creativecommons.org/licenses/by/ $4.0 /)$.

\begin{abstract}
For many decades, researchers have been working on finding innovative and sustainable solutions to address the enormous quantities of plastic waste that are produced every year which, after being collected, are transformed into energy, recycled, or sent to landfills. Giving a second life to plastic waste as a material to be incorporated, in the form of macro-fibres, into concrete, could be one such solution. The purpose of this study was to analyse the mechanical and physical behaviour of the hardened concrete reinforced with macro plastic fibres (RPFs) obtained from food packaging waste (FPW) discarded during the packaging phase. By varying the quantity of macro-fibres used, physical and mechanical properties such as compressive strength, modulus of elasticity, flexural strength, and toughness were evaluated. It was observed that, although the presence of macro plastic fibres reduced the mechanical resistance capacity compared to that of traditional concrete, their contribution proved to be of some importance in terms of toughness, bringing an improvement in the post-crack resistance of the composite material. This innovative mixture provides a further impulse to the circular economy.
\end{abstract}

Keywords: circular economy; recycled macro plastic fibres; physical properties; mechanical properties; toughness

\section{Introduction}

Concrete is a widely used construction material worldwide due to its great availability of raw materials and low cost [1]. Although concrete has good compressive behaviour, it does not respond adequately under high tensile stresses. To alleviate this, steel reinforcements have usually been used to improve its tensile and flexural strengths [2-4]. However, in recent years, natural (mainly vegetable), steel, glass, and synthetic fibres have also been used [1]. Synthetic fibres help to prevent plastic shrinkage cracks in fresh concrete [5], and improve concrete performance after cracking [6].

In recent years, the EU and its member states have endowed themselves with harmonized European standards regarding the production, classification, and use of FRC (fibre-reinforced concrete) (EN 14889-1 for steel fibres, and EN 14889-2 for polymer fibres). The current trend of international legislation, therefore, is to produce a fibre-reinforced concrete (FRC) that can be classified on the basis of its guaranteed performance, and not just the volumetric percentage of fibres contained within it (EN 206:2013 + A1:2016).

Plastic fibres are synthetic fibres that are known to help improve the ductility, crack resistance, and impact resistance of conventional concrete. However, the contribution of the addition of these fibres was found to be less significant with respect to compressive strength and flexural strength [1]. Kazmi et al. [7], for their part, after investigating the fracture behaviour, mechanical characteristics, and microstructure of recycled aggregate 
concrete, observed an increase in mechanical properties-particularly, split tensile strength and residual flexural tensile strength-with the increase in dosage of these synthetic fibres.

Plastic fibres can be in the form of micro plastic fibres or macro plastic fibres [1]. Micro plastic fibres refer to plastic fibres with diameters ranging from 5 to $100 \mu \mathrm{m}$ and lengths ranging from 5 to $30 \mathrm{~mm}$ [8]; they are used to control plastic shrinkage cracking [9], which is caused by the shrinkage of fresh concrete during the first $24 \mathrm{~h}$ after placement due to excessive evaporation of bleed water [10]. Macro plastic fibres, which were used in this study, normally have a length of $30-60 \mathrm{~mm}$ and a cross-section of $0.6-1 \mathrm{~mm}^{2}$ [11]; these are used not only to control plastic shrinkage [12], but also to control drying shrinkage [6]. Another significant benefit is the post-cracking performance provided by the addition of macro plastic fibres $[13,14]$.

On the other hand, world plastic production reached almost 368 million tons in 2019, of which approximately 58 million tons was generated in the EU (European Union). Of all the plastic produced in the EU in the year 2019, more than $20 \%$ was used in the building and construction sector, while almost $40 \%$ was used in packaging [15].

In the EU, in $2018,24.9 \%$ of collected plastic waste was landfilled, $42.6 \%$ was transformed into energy (by incineration [16]), and the remaining 32.5\% was intended for recycling [15]. According to a recent report [16], the target set by the new EU Directive $2019 / 852$ provides for the achievement of a recycling percentage of plastic for packaging of $50 \%$ by 2025 , and $55 \%$ by 2030 . Hence, plastic wastes are universally considered to be a threat to the environment [17].

Among the various types of recycling management approaches, the reuse of waste and recycled plastic material in the construction industry is considered an ideal method for disposing of plastic waste [18]. A review has been published recently about current trends in plastic waste composites as construction materials [19], reporting diverse uses of the most common plastics, such as polypropylene (PP), polyethylene (PE), and polyethylene terephthalate (PET), after proper recycling treatment-for instance, in bricks, as aggregate or filler in concrete, or as reinforcement in concrete in paving tiles or slabs. Benefits and drawbacks are weighed, highlighting as benefits the fact that its use increases its value, so recycling is encouraged, and raw material consumption is reduced; meanwhile, as drawbacks, sorting and selection, and the lack of study of recycled plastic waste in construction materials, are cited. Other studies, such as the one carried out by Platon et al. [20], dealt with other uses, such as the production of composite materials for sound insulation purposes produced by thermocompacting mixed plastic waste, from the production process of sanitary wares, and thermoplastic polymers.

The use of recycled aggregates from plastic waste to replace natural aggregates has been previously studied. Mohammadinia et al. [21] showed the feasibility of substituting up to $50 \%$ of natural aggregates for a combination of recycled plastic and glass aggregates in the construction of concrete footpaths. Corbu et al. [22] found that a combination of recycled aggregates from waste plastic and waste glass can totally replace natural aggregates in precast concrete pieces. Thorneycroft et al. [23] proved the feasibility of substituting up to $10 \%$ by volume of sand for recycled plastics in the manufacture of concrete. Elsewhere, Merlo et al. [24] detected a lack of adhesion between recycled plastic and cementitious matrix, explaining the loss of mechanical properties as ratio incorporation increased.

In addition, authors such as Foti went even further, studying the use of PET plastic waste in strips of large size [25] or in grids of macro-strips [26] as reinforcements in concrete, suggesting the possibility of being considered for the reinforcement of concrete in place of steel. Within this sector, recycled plastic fibres can be used in FRC, which allows improvement of the concrete properties, in addition to the environmental benefits that this entails $[4,18,27,28]$.

The global value of the packaging industry is around EUR 345 million, of which the EU accounts for one-third, and of which $50 \%$ is related to food packaging. Forecasts indicate that the sector will continue to grow both in size and in importance [29]. In terms of structure, monolayer and multilayer can be distinguished: monolayer films consist of a 
thermoplastic polymer sheet made mostly of PE, PP, or PET, with a range from 20 to $200 \mu \mathrm{m}$ of thickness, while multilayer films are made up of a different number of sheets that can be polymeric (thermoplastics) or non-polymeric materials (paper or aluminium foils) [30]. Multilayer plastic waste used in food packaging does not enter the waste recycling stream due to the wide variety of materials, its multilayer composition [31], and the colours that make up the food packaging; hence, a call for a circular economy is proposed [32]. Currently, the technical feasibility of recycling this waste at low cost is not close to being achieved [31,33]. Indeed, due to the fact that it is not always managed properly, the recycling process is quite complex and, with the great environmental concern attached, the plastic sector is encouraged to participate in projects to deal with this issue [34,35].

This confirms the need to address studies such as the present work, which are essential in finding solutions that transform plastic waste from packaging into new resources, enabling not only contribution to the circular economy, but also the production of innovative materials for civil construction.

In particular, this study deals with the analysis of the mechanical behaviour of concrete with the addition of macro-fibres obtained by cutting plastic sheets; specifically, measurements such as crack mouth opening displacement (CMOD) and toughness were obtained. Three different levels of fibre addition were used in the production of concrete $\left(2 \mathrm{~kg} / \mathrm{m}^{3}\right.$, $4 \mathrm{~kg} / \mathrm{m}^{3}$, and $6 \mathrm{~kg} / \mathrm{m}^{3}$ ), and two reference concretes were produced (one without fibre, and another with a commercial fibre). The main novelty of this research consists of having used not commercial plastic fibres, but waste material derived from the processing of plastic for food packaging. These multilayer plastic wastes are difficult to recycle due to their heterogeneous composition. Hence, this work aims to valorise this waste, contributing to a circular economy.

\section{Materials and Methods}

\subsection{Recycled Plastic Fibres (RPFs) from Food Packaging Waste (FPW)}

The recycled plastic waste (RPW) consisted of macro plastic fibres obtained from the waste derived from the production and processing of plastic, supplied in waste rolls by a local company that deals with the production of multilayer plastic for packaging. The plastic sheet was made of four overlapping layers of different materials: polyester, aluminium, biaxially oriented polyamide, and polypropylene (PET + ALU + OPA STE + PP $\mathrm{G})$. The fibres used in the experimentation were obtained in the laboratory by cutting plastic sheets (Figure 1a,b). A commercial polypropylene fibre (CPF) was also used as a comparison (Figure 1c). The fibres were in compliance with the EN 14889-2:2006 standard. The dimensions and main properties of the plastic fibres used are summarised in Table 1.

\subsection{Fibre-Reinforced Concrete (FRC) Specimens Made with RPF}

Specimens of PFRC were prepared by adding recycled plastic fibres (RPFs) to the concrete mix at 2,4 , and $6 \mathrm{~kg}$ per $\mathrm{m}^{3}$ of concrete. The prepared mixtures were assigned the following codes: PFRC-2, PFRC-4, and PFRC-6, respectively. Two control specimens were also prepared: a control specimen of concrete without reinforcement (C-REF), and fibre-reinforced concrete made with a commercial polypropylene fibre (PFRC-REF; dosage of $2 \mathrm{~kg}$ per $\mathrm{m}^{3}$ of concrete).

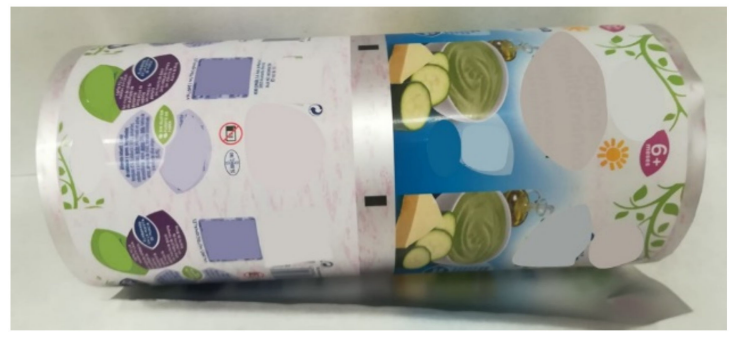

(a)

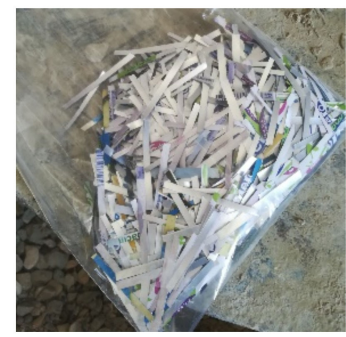

(b)

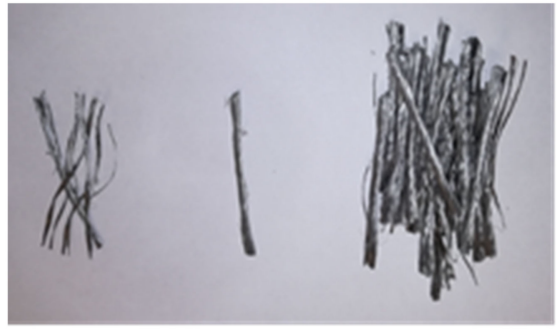

(c)

Figure 1. Plastic fibres: plastic waste rolls from food packaging (a); the prepared fibres (b); commercial polypropylene fibre (c). 
Table 1. Technical data of recycled plastic fibres (RPFs) and commercial polypropylene fibre (CPF).

\begin{tabular}{cccc}
\hline Technical Data & Unit & RPF & CPF \\
\hline Thickness & $\mathrm{mm}$ & 0.125 & - \\
Width & $\mathrm{mm}$ & 4 & - \\
Length & $\mathrm{mm}$ & 50 & 50 \\
Diameter & $\mathrm{mm}$ & - & 0.682 \\
Aspect ratio & - & 63.00 & 73.53 \\
Density & $\mathrm{g} / \mathrm{cm}^{3}$ & 1.13 & 0.91 \\
Tensile strength & $\mathrm{MPa}$ & 500 & 530 \\
Modulus of elasticity & $\mathrm{GPa}$ & 9.0 & 7.4 \\
\hline
\end{tabular}

The aggregates used for manufacturing the concrete mixes in the laboratory were coarse gravel $(7-25 \mathrm{~mm})$ at $960 \mathrm{~kg}$ per $\mathrm{m}^{3}$ and sand $(0-7 \mathrm{~mm})$ at $970 \mathrm{~kg} \mathrm{per} \mathrm{m}^{3}$, both with a siliceous nature. A total of $280 \mathrm{~kg}$ of CEM II $42.5 \mathrm{AV}-\mathrm{R}$ cement per $\mathrm{m}^{3}$ of concrete produced was used, reaching a water-to-cement ratio of 0.54 . In order to improve the workability and avoid segregation of the mixture, along with having an S3 slump class according to UNE-EN 206:2013 + A1:2018, two different types of additives were used: the plasticizer Complast MR260 at $5 \mathrm{~mL}$ per kg of cement, and the superplasticizer Structuro 357 at $7.7 \mathrm{~mL}$ per $\mathrm{kg}$ of cement. The slump ranged between $15 \mathrm{~cm}$ for C-REF and $10 \mathrm{~cm}$ for PFRC-6 mix. Slump values decreased as macro-fibre content increased, in agreement with the findings of other authors [18]. The concrete produced for each single mixture was casted, resulting in nine cubic specimens with a length of $100 \mathrm{~mm}$, three prismatic beams measuring $100 \mathrm{~mm} \times 100 \mathrm{~mm} \times 400 \mathrm{~mm}$, and six cylindrical specimens with a diameter of $150 \mathrm{~mm}$ and a height of $300 \mathrm{~mm}$, which were then cured in a climatic chamber (at $20{ }^{\circ} \mathrm{C}$ and $95 \% \pm 5 \%$ relative humidity) and subjected to testing at various ages.

\section{Experimental Methods}

\subsection{Physical Properties}

The dry density and the open porosity of the concrete specimens were obtained following the standard UNE 83980:2014. The performance of the mix concrete in terms of capillarity was determined using the Fagerlund method, following the standard UNE 83982:2008. Both tests were carried out on three cubic specimens with a length of $100 \mathrm{~mm}$.

\subsection{Compressive Strength}

The compressive strength test was performed in accordance with the UNE-EN 123502:2009 standard; it was carried out on three cubic specimens with a length of $100 \mathrm{~mm}$ after 7 and 28 days of curing, as well as on three cylindrical specimens with a height of $300 \mathrm{~mm}$ and a diameter of $150 \mathrm{~mm}$ after 28 days of curing.

\subsection{Elastic Modulus}

The elastic modulus was determined, in accordance with UNE-EN 12390-13:2014, after 28 days of curing on three cylindrical specimens $(\varnothing 150 \times 300 \mathrm{~mm})$.

\subsection{Flexural Strength}

The flexural strength was determined using three prismatic specimens $\left(400 \times 100 \times 100 \mathrm{~mm}^{3}\right.$ by length $\times$ width $\times$ height $)$ after 28 days of curing. The tests were carried out using a four-point bending tensile testing machine, with notch-opening control, complying with the UNE 83509:2004 standard.

\subsection{CMOD and Toughness}

The toughness index and CMOD were determined for each mixture by subjecting three prismatic specimens (equal to the flexural strength ones), notched ( $5 \mathrm{~mm}$ in width and $20 \mathrm{~mm}$ in height) in the central part, to a four-point bending tensile test, after 28 days of curing, in accordance with the UNE 83510:2004 standard. 
The measurement of the crack opening at the mouth of the notch of the specimen (CMOD) was performed using two linear variable displacement transducers (LVDTs) attached to the bottom of the concrete specimen. At the end of the test, the fissure was unique and corresponded to the notch. During the test, the applied loads and the corresponding opening of the notch made along the centre of the specimen were detected and recorded, thus obtaining, for each mix design, the load-CMOD curve. From the load-CMOD curve, the load and the relative resistance at the point of first cracking of the specimen were determined. The values of toughness $\mathrm{T}(\mathrm{N} \cdot \mathrm{m})$ were obtained by calculating the area under the load-deflection curve, from the point where the linear section of the diagram began, and up to the point where the arrow reached the value of $1 / 150$ of the span between the supports of the specimen. The toughness index, $\mathrm{I}_{30}$, was obtained as the ratio between the area under the curve from the origin of the curve to the point where the deflection reached the value of 15.5 times the deflection corresponding to the formation of the first crack, and the area under the curve between the origin of the curve and the deflection related to the first crack.

\section{Results and Discussion}

\subsection{Physical Properties}

The results of the dry density and water absorption in concrete samples are depicted in Table 2. The dry density values ranged between $2.21 \mathrm{~g} / \mathrm{cm}^{3}$ and $2.25 \mathrm{~g} / \mathrm{cm}^{3}$ for mixtures with recycled fibres, and between 2.26 and $2.27 \mathrm{~g} / \mathrm{cm}^{3}$ for reference concretes. Thus, owing to the small volume fraction of the plastic fibre added to the concrete, there was no significant reduction in the density of plastic FRC as compared to the density of conventional concrete, in accordance with the findings of de Oliveira and Castro-Gomes [36], Gu and Ozbakkaloglu [18], Han et al. [37], Karahan and Otis [38], and Richardson [39].

Table 2. Results of the test methods conducted on concrete samples, related to their physical properties.

\begin{tabular}{|c|c|c|c|c|c|}
\hline Test Methods $\backslash$ Mixes & C-REF & PFRC-REF & PFRC-2 & PFRC-4 & PFRC-6 \\
\hline Dry density $\left(\mathrm{g} / \mathrm{cm}^{3}\right)$ & $2.27(0.01)$ & $2.26(0.01)$ & $2.24(0.01)$ & $2.25(0.01)$ & $2.21(0.02)$ \\
\hline Open porosity (\%) & $11.84(0.24)$ & $14.15(0.31)$ & $12.21(0.20)$ & $12.17(0.44)$ & $13.34(0.49)$ \\
\hline $\begin{array}{l}\text { Effective porosity of concrete, } \varepsilon_{\mathrm{e}} \\
\qquad\left(\times 10^{-2} \mathrm{~cm}^{3} / \mathrm{cm}^{3}\right)\end{array}$ & $5.48(0.38)$ & $8.72(0.65)$ & $6.30(0.20)$ & $6.55(0.08)$ & $6.53(0.07)$ \\
\hline $\begin{array}{l}\text { Resistance to water penetration by } \\
\text { capillarity absorption, } \mathrm{m}\left(\mathrm{min} / \mathrm{cm}^{2}\right)\end{array}$ & $33.22(1.01)$ & $34.64(4.70)$ & $27.62(0.62)$ & $28.39(1.79)$ & $24.98(0.90)$ \\
\hline $\begin{array}{l}\text { Capillary absorption coefficient, } \mathrm{K} \\
\left(\times 10^{-2} \mathrm{~kg} /\left(\mathrm{m}^{2} \cdot \mathrm{min}^{1 / 2}\right)\right.\end{array}$ & $9.51(0.50)$ & $14.81(0.60)$ & $11.98(0.44)$ & $12.30(0.27)$ & $13.08(0.37)$ \\
\hline $\begin{array}{l}\text { The standard deviation is shown in } \\
\text { parentheses }\end{array}$ & & & & & \\
\hline
\end{tabular}

The open porosity (Table 2) of concretes with recycled fibres presented values between $12.17 \%$ and $13.34 \%$, compared to between $11.84 \%$ and $14.15 \%$ for reference concretes. In all cases, the concretes made with fibres presented higher porosity values than the concrete made without them (C-REF). However, mixtures with recycled fibres presented lower values than those obtained for concrete made with commercial polypropylene fibres (PRFC-REF).

Even the effective porosity of concrete, with values ranging from $5.48 \times 10^{-2} \mathrm{~cm}^{3} / \mathrm{cm}^{3}$ to $8.72 \times 10^{-2} \mathrm{~cm}^{3} / \mathrm{cm}^{3}$ (corresponding to the reference mixture), did not undergo significant variation.

The resistance to water penetration by capillarity absorption, and the capillary absorption coefficient-with values ranging between $24.98 \mathrm{~min} / \mathrm{cm}^{2}$ and $34.64 \mathrm{~min} / \mathrm{cm}^{2}$ and between $9.51 \times 10^{-2} \mathrm{~kg} /\left(\mathrm{m}^{2} \cdot \mathrm{min}^{1 / 2}\right)$ and $14.81 \times 10^{-2} \mathrm{~kg} /\left(\mathrm{m}^{2} \cdot \mathrm{min}^{1 / 2}\right)$, respectivelyhighlighted a slight decline in resistance to water penetration by capillarity absorption, and a slight increase in the capillary absorption coefficient compared to the reference values. This is consistent with the studies carried out by other researchers [40,41], who reported 
that the addition of plastic fibres to concrete does not affect the properties studied, since the values obtained differ little from those of the fibre-free concrete mix.

Karahan and Atis [38], on the other hand, indicated that the water porosity and the water absorption capacity of concrete containing PP fibres (with concentrations lower than $0.20 \%$ ) increased compared to the corresponding value for the control mix.

\subsection{Compressive Strength}

As can be seen from the graphs in Figure 2, the addition of RPF to the mixture reduced the compressive strength at 7 days and 28 days in the cubic specimens, as well as in the cylindrical specimens at 28 days. This reduction increased with the increase in the amount of fibre added. The percentage variations in the compressive strength, as a function of the type and quantity of fibre, compared to the control specimen (C-REF), exhibited, for the cubic specimens at 7 days of curing, decreases of $16.66 \%$ for PFRC-REF, $31.72 \%$ for PFRC-2, 32.68\% for PFRC-4, and 31.62\% for PFRC-6. For the cubic specimens, at 28 days of curing, the corresponding decreases were $15.95 \%$ for PFRC-REF, $20.73 \%$ for PFRC-2, $23.98 \%$ for PFRC-4, and $26.28 \%$ for PFCR-6. From these data, it can be seen that the compressive strength, in the cubic specimens, underwent a minor reduction compared to C-REF, with an increase in curing time. For the cylindrical specimens, at 28 days of curing, the corresponding decreases were $18.39 \%$ for PFRC-2, 36.78\% for PFRC-2, 47.89\% for PFRC-4, and $54.38 \%$ for PFRC- 6 .

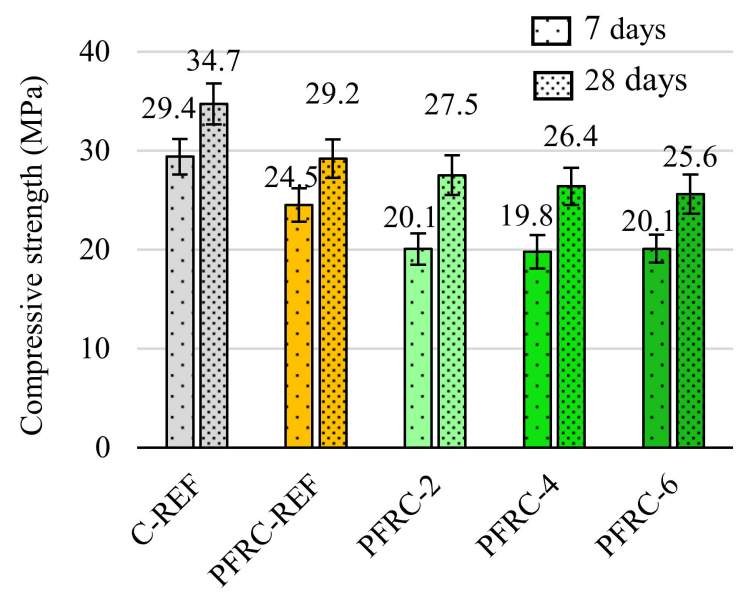

(a)

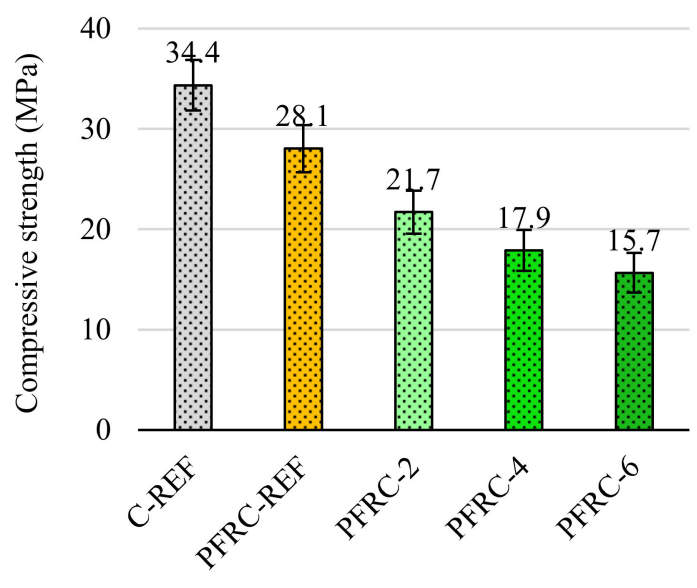

(b)

Figure 2. Compressive strength values for each mixture, along with the standard deviation bands: at 7 and 28 days ( $\left.f_{c k, c u b e}\right)$ (a); at 28 days $\left(\mathrm{f}_{\mathrm{ck}, \mathrm{cyl}}\right)(\mathbf{b})$.

For the cylindrical specimens, there was a greater reduction in compressive strength than recorded for the cubic specimens. This behaviour could be attributed to the different manufacturing methods of the two types of specimens, i.e., the vibrating method for cubic specimens and tamping with a steel rod for cylindrical specimens. Furthermore, the similar compressive strength performance presented by cubic specimens with RPF and CPF can be highlighted.

In general, a reduction in compressive strength with an increase in RPF content occurred, consistent with the investigations of Kim et al. [42] and Meddah and Bencheikh [29]. This could, according to some authors, have been due to the poor homogeneity and compactness of the mixture $[43,44]$, or to other factors such as (1) the formation of zones inside the mixture where stress concentrations are created that favour the propagation of damage, (2) a weak connection at the concrete-plastic fibre interface, (3) an increase in air content [45], and (4) the presence of further voids due to the fibres $[4,46]$.

However, other researchers-such as de Oliveira and Castro-Gomes [36], Han et al. [37], Hsie et al. [47], Gu and Ozbakkaloglu [18], and Kakooei et al. [48]—reported the oppo- 
site, i.e., that the compressive strength of the concrete improved upon the addition of plastic fibre.

\subsection{Elastic Modulus}

Figure 3 shows the variation in the values of elastic modulus $\left(\mathrm{E}_{\mathrm{cm}}\right)$ with the quantity of recycled plastic fibres. There is no consensus in the literature with respect to this property. Kim et al. [42] reported that, for all mixtures containing recycled plastic fibres, a decrease in $\mathrm{E}_{\mathrm{cm}}$ could be noted with respect to the values obtained in the control specimen. Other researchers observed an increase in $\mathrm{E}_{\mathrm{cm}}$ with an increase in the percentage of plastic fibre [4,49], whereas others-such as Pelisser et al. [50], Karahan and Atis [38], and Mazaheripour et al. [51] —indicated that the $\mathrm{E}_{\mathrm{cm}}$ of the plastic FRC did not differ significantly from that of conventional concrete. Our results (Figure 3) were consistent with this latter finding, since the mixtures made with plastic fibres showed very similar values, except for PFRC-2, which showed an increase of 31\% with respect to its reference counterpart (PFRC-REF). This could be attributed to the greater modulus of elasticity presented by the FRP than the CPF, as seen in Table 1.

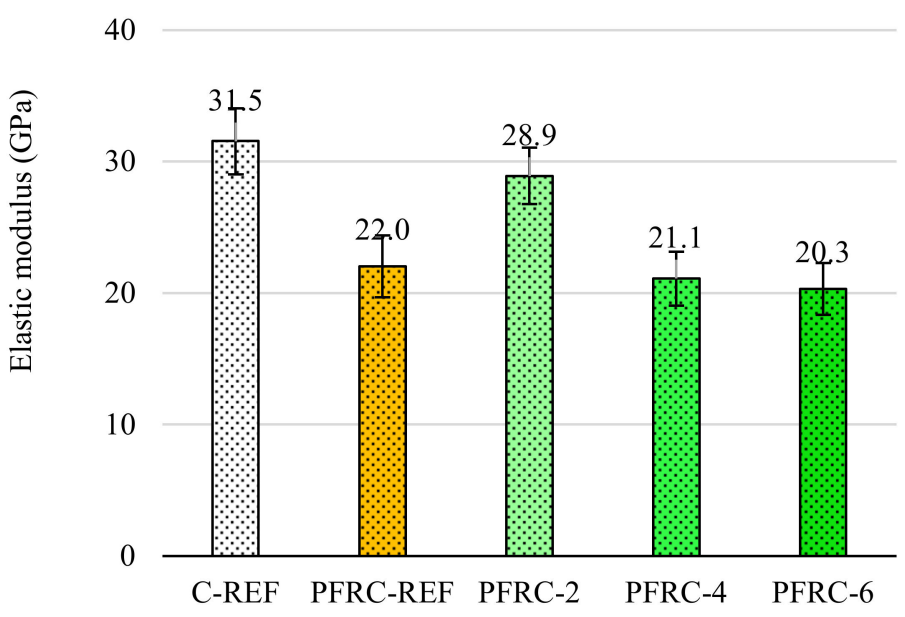

Figure 3. Elastic modulus $\left(\mathrm{E}_{\mathrm{cm}}\right)$ values for all mixtures at 28 days, along with the standard deviation bands.

\subsection{Flexural Strength}

Most previous studies observed that the flexural strength of concrete increased upon the addition of PF [36,50-54].

However, as can be seen in Figure 4, the flexural strength recorded for non-notched prismatic specimens underwent a considerable reduction for mixtures made with fibres compared to the control concrete specimen (C-REF). The results also show that, as the percentage of fibre increased, a significant reduction in flexural strength followed. This is consistent with the findings of other authors $[55,56]$, who stated that the flexural strength only improved when the concrete had a low fibre content, whereas, above a certain threshold, the flexural strength decreased (which coincides with our case).

With respect to the values of the control concrete specimen (C-REF), the decreases were $28.45 \%$ for PFRC-REF, 39.79\% for PFRC-2, 45.03\% for PFRC-4, and $49.04 \%$ for PFRC- 6 . According to other researchers, the reduction in flexural strength may have been due to the presence of voids inside the concrete matrix [46], which depends mainly on the strength of the mix, as seen in concrete specimens with fibres compared to C-REF. 


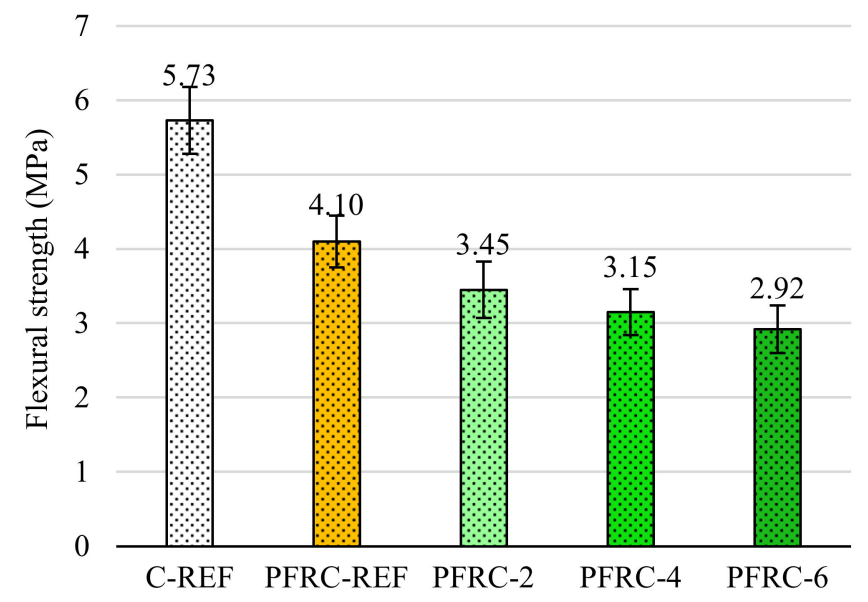

Figure 4. Flexural strength values for all mixtures, along with the standard deviation bands.

\subsection{Toughness}

The experimental curves of the relationship between the applied load (F) and the CMOD as a function of the type and quantity of fibre used in the mixture are presented in Figure 5, where the punctual values of the crack opening are shown on the $x$-axis. After reaching the point of first cracking, there was a sudden drop in load, probably caused by both the failure of the anchoring of some fibres and the breakage of others. In correspondence with the broken surface of the specimen, slipped and broken fibres were present. The post-cracking phase followed, during which the plastic fibres began to make their contribution and the deformation energy was dissipated by the fibres with the consequent remaining load, which remained constant up to a CMOD of nearly $4.5 \mathrm{~mm}$, as depicted in Figure 5. This same behaviour was observed by many other researchers using different types of commercial or recycled plastic, and with different amounts of plastic fibre $[14,41,44,57]$.

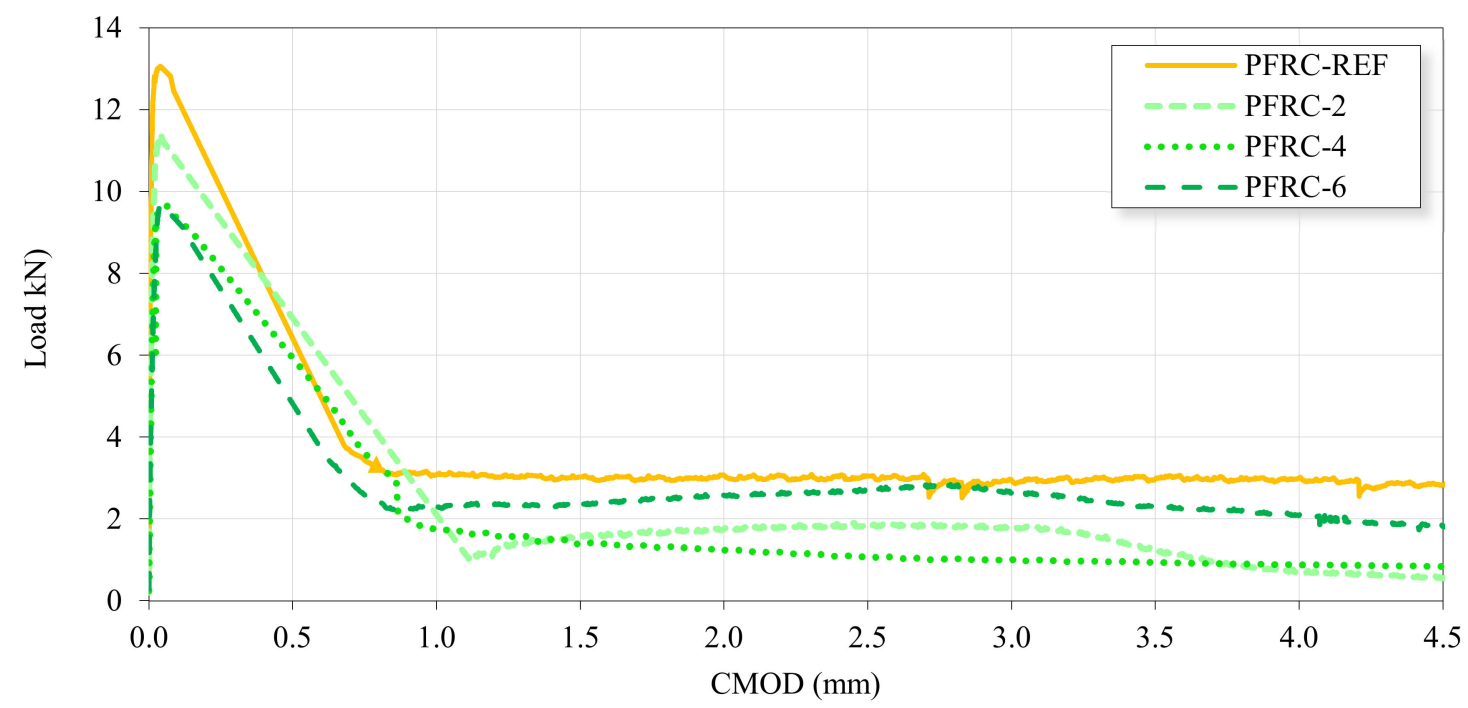

Figure 5. Average load-CMOD curves of three specimens of each concrete type.

Figure $6 \mathrm{a}$ shows the load-deflection graphs, while Figure $6 \mathrm{~b}$ shows the initial segments of the graphs obtained by linearly interpolating the forces between the values of $20 \%$ and 60\% of the peak force, where the first break occurred, as dictated by the UNE 83510: 2004 standard, which allowed us to calculate the toughness and the toughness index. The behaviour of the four mixtures was generally similar, wherein there was a first phase where the force increased until it reached its maximum value (peak value), and where the first 
crack occurred in the specimen. With regard to the mixture made with the addition of commercial plastic fibres, the graph displayed a value of peak force greater than that of the other three mixtures. Subsequently, there was a rapid decrease in strength, followed by a slight increase, which may have been due to the contribution of the plastic fibres contained within the mixture. Toward the end, the force gradually decreased until the specimen broke, showing a degrading type of post-cracking behaviour (softening behaviour). The same results were obtained by numerous other researchers who experimented with the addition of recycled plastic fibre to reinforce concrete, demonstrating that it is possible to obtain a concrete that has good mechanical characteristics in terms of toughness, as well as reduces environmental pollution by reusing material resources that would otherwise be disposed of in landfills $[12,27,58,59]$. In the post-cracking phase, the concrete mix with the highest fibre content (PFRC-6) exhibited a similar behaviour to the concrete mix with commercial fibre (PFRC-REF).

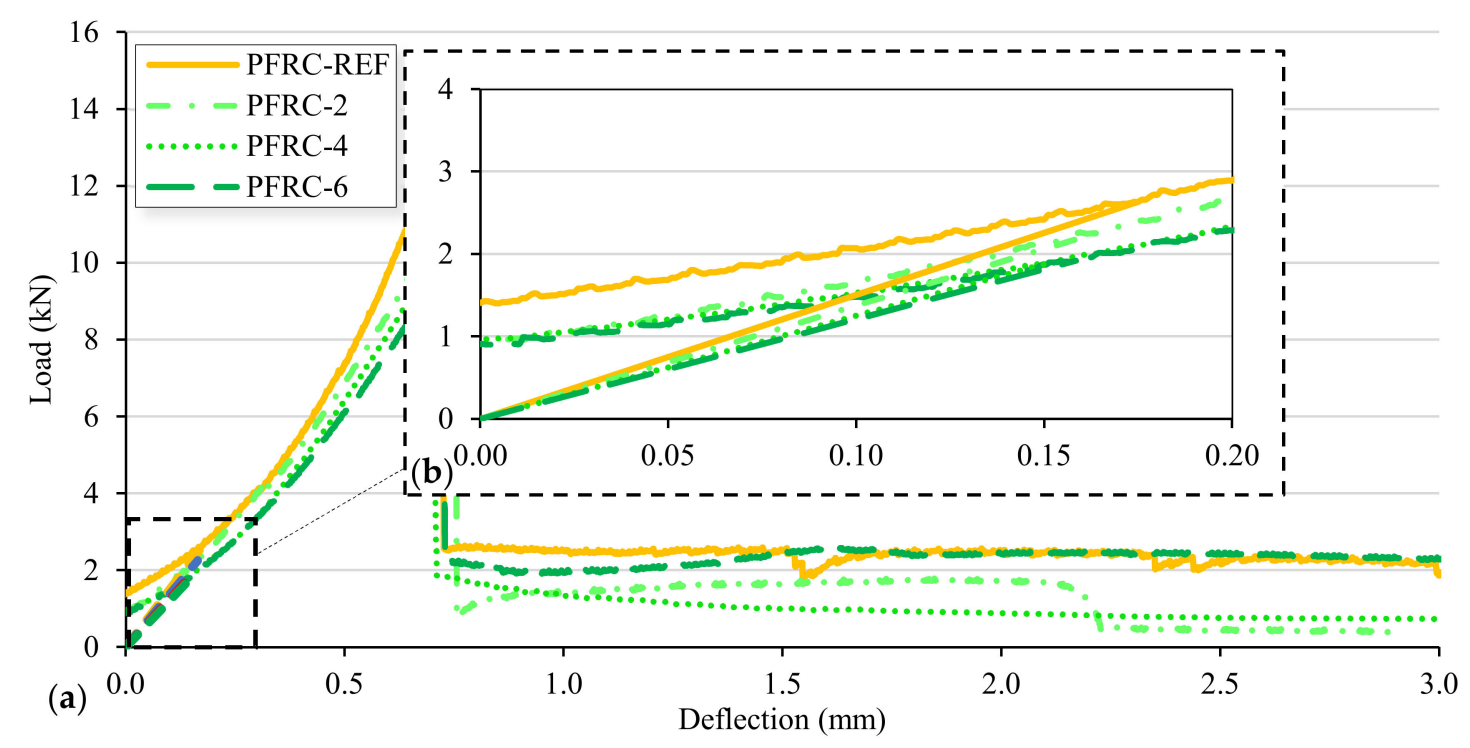

Figure 6. Load-deflection curves of each concrete type (a); detailed view of the initial section of the curve (b).

Figure 7 shows that the presence of plastic fibres inside the matrix increased both the ability of the concrete to resist the advancement of cracks, and its ability to absorb energy and deform plastically before breaking, giving the compound a certain residual tensile strength after the microcracking of the cement matrix. In Figure 7a, it can be seen how the toughness of the concrete with commercial fibre (PFRC-REF) was higher than that of the concrete with recycled fibre (PFRC-2) when using the same quantity of fibre. This was mainly due to the commercial fibre used in this study having a much rougher surface than the surface of the recycled fibre, which was practically smooth. The increase in toughness index (Figure $7 \mathrm{~b}$ ) resulted in the value of the strength index of the mixture with no fibre addition (C-REF) being equal to 1 . An increase in the percentage of recycled fibre confirmed the stitching action of the fibres themselves inside the cement matrix, which was fundamentally dependent on the type of fibre and its quantity. Comparing the RPF concrete specimens with the reference (PFRC-REF), the toughness index increased with $\mathrm{RPF}$ dosage, reaching similar levels at $6 \mathrm{~kg}$ of RPF per $\mathrm{m}^{3}$ of concrete. 


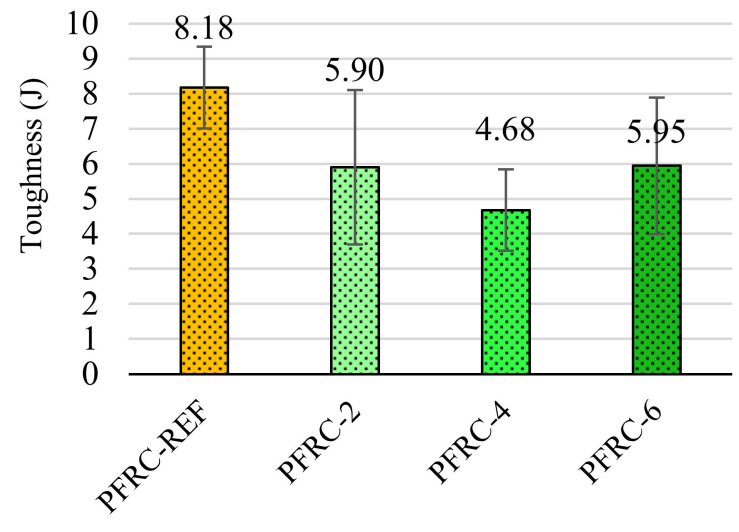

(a)

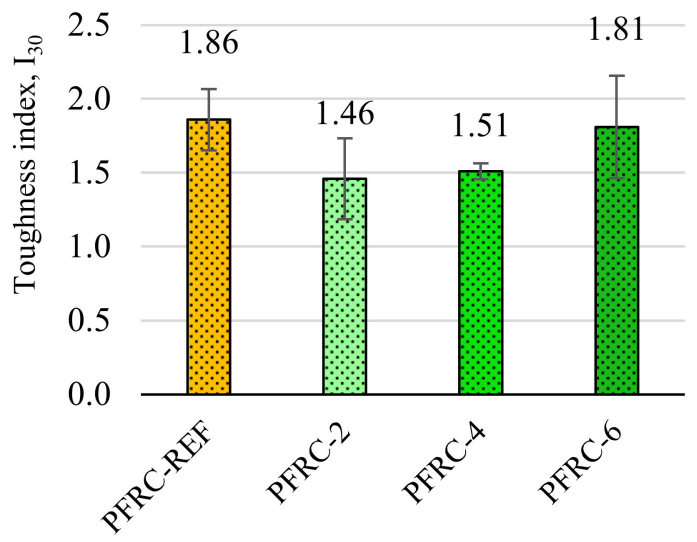

(b)

Figure 7. Values of toughness (a) and toughness index (b).

\section{Conclusions}

This study addressed the use of fibre from multilayer recycled plastic from food packaging plastic waste for reinforcement in concrete. Considering the results, the following conclusions can be drawn from this research:

- The physical properties studied were not significantly affected by the addition of recycled plastic fibres;

- The addition of RPF produces a certain decrease in compressive and flexural strength, but an improvement in the post-cracking properties of the concrete was achieved. The presence of plastic fibres inside the matrix increased both the ability of the concrete to resist the advancement of cracks, and its ability to deform plastically before breaking, giving the concrete matrix a certain residual tensile strength during the post-crack phase;

- The increase in toughness index with an increase in the percentage of recycled plastic fibres confirmed their stitching action inside the cement matrix, which is fundamentally dependent on the type of fibre and its quantity;

- The toughness index presented by the concrete with commercial fibres was greater than that with the same dosage of RPF, due to its rougher surface and greater adherence to the cementitious matrix. Furthermore, it should be noted that the toughness index relative to the mixture with $6 \mathrm{~kg}$ of recycled plastic fibres per cubic meter of concrete was comparable to that with commercial plastic fibre (PFRC-REF). This suggests that manufacturing RPF with a rougher surface could lead to a reduction in the amount needed to achieve similar toughness index levels to PFRC-REF.

In addition to the mechanical characteristics mentioned above, the use of recycled fibre from multilayer plastic waste derived from the packaging industry-which is currently difficult to recycle-in the production of this composite material could be an interesting approach to extend the life cycle of this material.

Author Contributions: Conceptualization, J.A. and A.P.G.; methodology, A.L.-U.; Software, A.L.-U. and P.A.V.; Validation, J.A. and A.P.G. formal analysis, P.A.V. and A.B.; investigation, P.A.V. and A.L.-U.; resources, A.P.G.; data curation, P.A.V. and A.L.-U.; writing-original draft preparation, P.A.V. and A.L.-U.; writing-review and editing, A.B. and J.A.; visualization, P.A.V.; supervision, A.L.-U., J.A. and A.B; project administration, J.A. and A.P.G.; funding acquisition, J.A. and A.P.G. All authors have read and agreed to the published version of the manuscript.

Funding: This research received no external funding.

Institutional Review Board Statement: Not applicable.

Informed Consent Statement: Not applicable. 


\section{Data Availability Statement: Not applicable.}

Acknowledgments: The authors would like to express their gratitude to the SP-Group CENTRAL CÓRDOBA-Plastienvase SL for their efficient service, professionalism, and support to the present study. The authors also thank the Votorantim Group for freely providing the cement used in this research.

Conflicts of Interest: The authors declare no conflict of interest.

\section{References}

1. Yin, S.; Tuladhar, R.; Shi, F.; Combe, M.; Collister, T.; Sivakugan, N. Use of macro plastic fibres in concrete: A review. Constr. Build. Mater. 2015, 93, 180-188. [CrossRef]

2. Beglarigale, A.; Yazıc1, H. Pull-out behavior of steel fiber embedded in flowable RPC and ordinary mortar. Constr. Build. Mater. 2015, 75, 255-265. [CrossRef]

3. Buratti, N.; Ferracuti, B.; Savoia, M. Concrete crack reduction in tunnel linings by steel fibrereinforced concretes. Constr. Build. Mater. 2013, 44, 249-259. [CrossRef]

4. Mohammed, A.A.; Rahim, A.A.F. Experimental behavior and analysis of high strength concrete beams reinforced with PET waste fiber. Constr. Build. Mater. 2020, 244, 118350. [CrossRef]

5. Cao, M.; Zhang, C.; Lv, H. Mechanical response and shrinkage performance of cementitious composites with a new fiber hybridization. Constr. Build. Mater. 2014, 57, 45-52. [CrossRef]

6. Pujadas, P.; Blanco, A.; Cavalaro, S.; de la Fuente, A.; Aguado, A. Fibre distribution in macro-plastic fibre reinforced concrete slab-panels. Constr. Build. Mater. 2014, 64, 496-503. [CrossRef]

7. Kazmi, S.M.S.; Munir, M.J.; Wu, Y.F.; Patnaikuni, I. Effect of macro-synthetic fibers on the fracture energy and mechanical behavior of recycled aggregate concrete. Constr. Build. Mater. 2018, 189, 857-868. [CrossRef]

8. Nili, M.; Afroughsabet, V. The effects of silica fume and polypropylene fibers on the impact resistance and mechanical properties of concrete. Constr. Build. Mater. 2010, 24, 927-933. [CrossRef]

9. Soutsos, M.N.; Le, T.T.; Lampropoulos, A.P. Flexural performance of fibre reinforced concrete made with steel and synthetic fibres. Constr. Build. Mater. 2012, 36, 704-710. [CrossRef]

10. Güneyisi, E.; Gesoğlu, M.; Mohamadameen, A.; Alzeebaree, R.; Algın, Z.; Mermerdaş, K. Enhancement of shrinkage behavior of lightweight aggregate concretes by shrinkage reducing admixture and fiber reinforcement. Constr. Build. Mater. 2014, 54, 91-98. [CrossRef]

11. Yin, S.; Tuladhar, R.; Shanks, R.A.; Collister, T.; Combe, M.; Jacob, M.; Sivakugan, N. Fiber preparation and mechanical properties of recycled polypropylene for reinforcing concrete. J. Appl. Polym. Sci. 2015, 132. [CrossRef]

12. Chavooshi, A.; Madhoushi, M. Mechanical and physical properties of aluminum powder/MDF dust/polypropylene composites. Constr. Build. Mater. 2013, 44, 214-220. [CrossRef]

13. Buratti, N.; Mazzotti, C.; Savoia, M. Postcracking behaviour of steel and macrosynthetic fibrereinforced concretes. Constr. Build. Mater. 2011, 25, 2713-2722. [CrossRef]

14. Nana, W.S.A.; Tran, H.V.; Goubin, T.; Kubisztal, G.; Bennani, A.; Bui, T.T.; Cardia, G.; Limam, A. Behaviour of macro-synthetic fibers reinforced concrete: Experimental, numerical and design code investigations. Proc. Struct. 2021, 32, 1271-1286. [CrossRef]

15. Association of Plastic Manufacturers. Plastics-The Facts 2020; PlasticEurope: Brussels, Belgium, 2020.

16. Siddique, R.; Khatib, J.; Kaur, I. Use of recycled plastic in concrete: A review. Waste Manag. 2008, 28, 1835-1852. [CrossRef]

17. Alani, A.H.; Bunnori, N.M.; Noaman, A.T.; Majid, T.A. Durability performance of a novel ultra-high-performance PET green concrete (UHPPGC). Constr. Build. Mater. 2019, 209, 395-405. [CrossRef]

18. Gu, L.; Ozbakkaloglu, T. Use of recycled plastics in concrete: A critical review. Waste Manag. 2016, 51, 19-42. [CrossRef]

19. Mohan, H.T.; Jayanarayanan, K.; Mini, K.M. Recent trends in utilization of plastics waste composites as construction materials. Constr. Build. Mater. 2020, 271, 121520. [CrossRef]

20. Platon, M.A.; Nemes, O.; Tiuc, A.E.; Vasile, O.; Paduretu, S. Phono-Absorbent Behavior of New Fiberglass Plates from Mixed Plastic Material Wastes. In Materials Design and Applications III; Springer: Berlin/Heidelberg, Germany, 2021; pp. 67-76. [CrossRef]

21. Mohammadinia, A.; Wong, Y.C.; Arulrajah, A.; Horpibulsuk, S. Strength evaluation of utilizing recycled plastic waste and recycled crushed glass in concrete footpaths. Constr. Build. Mater. 2019, 197, 489-496. [CrossRef]

22. Corbu, O.; Bompa, D.V.; Szilagyi, H. Eco-efficient cementitious composites with large amounts of waste glass and plastic. Proc. Inst. Civ. Eng. Eng. Sustain. 2021, 40, 1-11. [CrossRef]

23. Thorneycroft, J.; Orr, J.; Savoikar, P.; Ball, R.J. Performance of structural concrete with recycled plastic waste as a partial replacement for sand. Constr. Build. Mater. 2018, 161, 63-69. [CrossRef]

24. Merlo, A.; Lavagna, L.; Suarez-Riera, D.; Pavese, M. Mechanical properties of mortar containing waste plastic (PVC) as aggregate partial replacement. Case Stud. Constr. Mater. 2020, 13, e00467. [CrossRef]

25. Foti, D. Use of recycled waste pet bottles fibers for the reinforcement of concrete. Compos. Struct. 2013, 96, 396-404. [CrossRef]

26. Foti, D.; Paparella, F. Impact behavior of structural elements in concrete reinforced with PET grids. Mech. Res. Commun. 2014, 57, 57-66. [CrossRef] 
27. Tuladhar, R.; Yin, S. Sustainability of using recycled plastic fiber in concrete. In Use of Recycled Plastics in Eco-Efficient Concrete; Woodhead Publishing Series in Civil and Structural Engineering; Woodhead Publishing: Sawston, UK, 2019; pp. 441-460. [CrossRef]

28. Meddah, M.S.; Bencheikh, M. Properties of concrete reinforced with different kinds of industrial waste fibre materials. Constr. Build. Mater. 2009, 23, 3196-3205. [CrossRef]

29. Ahvenainen, R. Novel Food Packaging Techniques; CRC Press: Boca Raton, FL, USA; Woodhead Publishing: Sawston, UK, 2003.

30. Horodytska, O.; Valdés, F.J.; Fullana, A. Plastic flexible films waste management-A state of art review. Waste Manag. 2018, 77, 413-425. [CrossRef] [PubMed]

31. Mulakkal, M.C.; Castillo Castillo, A.; Taylor, A.C.; Blackman, B.R.K.; Balint, D.S.; Pimenta, S.; Charalambides, M.N. Advancing mechanical recycling of multilayer plastics through finite element modelling and environmental policy. Resour. Conserv. Recycl. 2021, 166, 105371. [CrossRef]

32. Soares, C.T.d.M.; Ek, M.; Östmark, E.; Gällstedt, M.; Karlsson, S. Recycling of multi-material multilayer plastic packaging: Current trends and future scenarios. Resour. Conserv. Recycl. 2022, 176, 105905. [CrossRef]

33. Kaiser, K.; Schmid, M.; Schlummer, M. Recycling of polymer-based multilayer packaging: A review. Recycling $2018,3,1$. [CrossRef]

34. SP GROUP Projects. Biobaractive. New Multi-Layer Biodegradable Packaging with High Gas-Barrier Properties and AntiMicrobial Properties for Increasing the Shelf Life of Processed Meats. JSIP-20150002. Available online: https:/ / www.spg-pack.com/en/biobaractive-new-multi-layer-biodegradable-packaging-with-high-gas-barrier-propertiesand-anti-microbial-properties-for-increasing-the-shelf-life-of-processed-meats / (accessed on 15 October 2021).

35. SP GROUP Projects. Project Reciclactive: "Delivering the Meat Industry New Sustainable, Recyclable Active Packaging Solutions". Available online: https:/ / www.spg-pack.com/en/project-reciclactive-delivering-the-meat-industry-new-sustainable-recyclableactive-packaging-solutions / (accessed on 15 October 2021).

36. De Oliveira, L.A.P.; Castro-Gomes, J.P. Physical and mechanical behaviour of recycled PET fibre reinforced mortar. Constr. Build. Mater. 2011, 25, 1712-1717. [CrossRef]

37. Han, C.-G.; Hwang, Y.-S.; Yang, S.-H.; Gowripalan, N. Performance of spalling resistance of high performance concrete with polypropylene fiber contents and lateral confinement. Cem. Concr. Res. 2005, 35, 1747-1753. [CrossRef]

38. Karahan, O.; Atiş, C.D. The durability properties of polypropylene fiber reinforced fly ash concrete. Mater. Des. 2011, 32, 1044-1049. [CrossRef]

39. Richardson, A.E. Compressive strength of concrete with polypropylene fibre additions. Struct. Surv. 2006, 24, 138-153. [CrossRef]

40. Alonso, M.C.; Sanchez, M.; Rodriguez, C.; Barragan, B. Durability of SCC reinforced with polymeric fibres: Interaction with environment and behaviour against high temperatures. In Proceedings of the 11th International Inorganic-Bonded Fibre Composites Conferences, Madrid, Spain, 5-7 November 2008; pp. 227-235.

41. De Miguel, P.C.; Álvarez, A.P.; Jiménez, J.P.G. Diseño optimizado y caracterización de hormigones autocompactantes reforzados con fibra polimérica de alto módulo. In Proceedings of the 3rd Congreso Iberoamericano Sobre Hormigón Autocompactante Avances y Oportunidades, Madrid, Spain, 3-4 December 2012.

42. Kim, S.B.; Yi, N.H.; Kim, H.Y.; Kim, J.-H.J.; Song, Y.C. Material and structural performance evaluation of recycled PET fiber reinforced concrete. Cem. Concr. Compos. 2010, 32, 232-240. [CrossRef]

43. Ghernouti, Y.; Rabehi, B.; Bouziani, T.; Ghezraoui, H.; Makhloufi, A. Fresh and hardened properties of self-compacting concrete containing plastic bag waste fibers (WFSCC). Constr. Build. Mater. 2015, 82, 89-100. [CrossRef]

44. Borg, R.P.; Baldacchino, O.; Ferrara, L. Early age performance and mechanical characteristics of recycled $\{$ PET $\}$ fibre reinforced concrete. Constr. Build. Mater. 2018, 108, 29-47. [CrossRef]

45. Jacob-Vaillancourt, C.; Sorelli, L. Characterization of concrete composites with recycled plastic aggregates from postconsumer material streams. Constr. Build. Mater. 2018, 182, 561-572. [CrossRef]

46. Ahmed, H.U.; Faraj, R.H.; Hilal, N.; Mohammed, A.A.; Sherwani, A.F.H. Use of recycled fibres in concrete composites: A systematic comprehensive review. Compos. B Eng. 2021, 215, 108769. [CrossRef]

47. Hsie, M.; Tu, C.; Song, P.S. Mechanical properties of polypropylene hybrid fiber reinforced concrete. Mater. Sci. Eng. A 2008, 494, 153-157. [CrossRef]

48. Kakooei, S.; Akil, H.M.; Jamshidi, M.; Rouhi, J. The effects of polypropylene fibers on the properties of reinforced concrete structures. Constr. Build. Mater. 2012, 27, 73-77. [CrossRef]

49. Thomas, L.M.; Moosvi, S.A. Hardened properties of binary cement concrete with recycled PET bottle fiber: An experimental study. Mater. Today Proc. 2020, 32, 632-637. [CrossRef]

50. Pelisser, F.; Montedo, O.R.K.; Gleize, P.J.P.; Roman, H.R. Mechanical properties of recycled PET fibers in concrete. Mater. Res. 2012, 15, 679-686. [CrossRef]

51. Mazaheripour, H.; Ghanbarpour, S.; Mirmoradi, S.H.; Hosseinpour, I.I. The effect of polypropylene fibers on the properties of fresh and hardened lightweight self-compacting concrete. Constr. Build. Mater. 2011, 25, 351-358. [CrossRef]

52. López-Buendía, A.M.; Romero-Sánchez, M.D.; Climent, V.; Guillem, C. Surface treated polypropylene (PP) fibres for reinforced concrete. Cem. Concr. Res. 2013, 54, 29-35. [CrossRef]

53. Ochi, T.; Okubo, S.; Fukui, K. Development of recycled $\{$ PET $\}$ fiber and its application as concretereinforcing fiber. Cem. Concr. Compos. 2007, 29, 448-455. [CrossRef] 
54. Toutanji, H.A. Properties of polypropylene fiber reinforced silica fume expansive-cement concrete. Constr. Build. Mater. 1999, 13, 171-177. [CrossRef]

55. Wang, Y.; Zureick, A.H.; Cho, B.S.; Scott, D. E Properties of fibre reinforced concrete using recycled fibres from carpet industrial waste. J. Mater. Sci. 1994, 29, 4191-4199. [CrossRef]

56. Nibudey, R.N.; Nagarnaik, P.B.; Parbat, D.K.; Pande, A.M. Strength and fracture properties of post consumed waste plastic fiber reinforced concrete. Int. J. Civ. Struct. Environ. Infrastruct. Eng. Res. Dev. 2013, 3, 9-16.

57. Yin, S.; Tuladhar, R.; Collister, T.; Combe, M.; Sivakugan, N.; Deng, Z. Post-cracking performance of recycled polypropylene fibre in concrete. Constr. Build. Mater. 2015, 101, 1069-1077. [CrossRef]

58. Foti, D. Preliminary analysis of concrete reinforced with waste bottles PET fibers. Constr. Build. Mater. 2011, $25,1906-1915$. [CrossRef]

59. Signorini, C.; Volpini, V. Mechanical Performance of Fiber Reinforced Cement Composites Including Fully-Recycled Plastic Fibers. Fibers 2021, 9, 16. [CrossRef] 